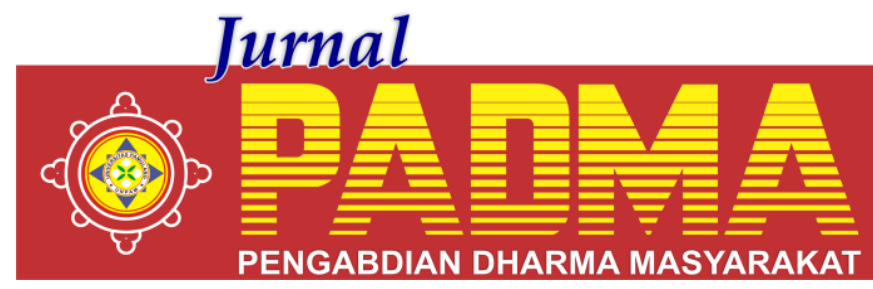

VOLUME 1, NOMOR 4, OKTOBER 2021

\title{
DAMPAK INTERNAL CONTROL PADA PENGELOLAAN SIKLUS KAS DALAM ORGANISASI
}

\author{
${ }^{1}$ Susi Sih Kusumawardhany, ${ }^{2}$ Yunita Kurnia Shanti, ${ }^{3 *}$ Sudarmadi, ${ }^{4}$ Mohamad Khaerul \\ Umam, ${ }^{5}$ Iqbal Aji Ramadhani, ${ }^{6}$ Desi Indraningsih \\ Universitas Pamulang, Tangerang Selatan, Banten, Indonesia \\ *dosen00752@unpam.ac.id
}

\begin{abstract}
Abstrak
Salah satu aktiva yang menunjang peranan penting dalam perkembangan perusahaan adalah kas. Kas merupakan salah satu aset perusahaan yang paling penting karena kas merupakan aset yang paling cair atau liquid. Aktivitas yang melibatkan kas diantaranya adalah pada siklus penerimaan dan pengeluaran kas, dimana dalam siklus inilah merupakan bagian yang paling mudah untuk dilakukan kecurangan maupun penyimpangan kas. Sehingga pengawasan yang ketat terhadap kas melalui pengendalian internal yang baik diperlukan untuk menekan terjadinya kecurangan dalam suatu organisasi. Pengendalian internal sangat penting bagi semua organisasi, termasuk pada organisasi dalam bentuk yayasan. Yayasan adalah sebuah organisasi atau badan hukum yang memiliki tujuan dan maksud yang tujuannya tersebut bersifat sosial, keagamaan dan kemanusiaan.
\end{abstract}

Kata Kunci: Pengendalian Internal

\section{Abstract}

One of the assets that support an important role in the development of the company is cash. Cash is one of the most important corporate assets because cash is the most liquid or liquid asset. Activities involving cash include the cycle of receipts and cash expenditures, which in this cycle is the easiest part to commit fraud or cash irregularities. So that strict supervision of cash through good internal control is needed to suppress fraud in an organization. Internal control is essential for all organizations, including those in the form of foundations. A foundation is an organization or legal entity that has a purpose and purpose whose purpose is social, religious and humanitarian.

Keywords: Internal Control

\section{PENDAHULUAN}

Yayasan Karya Peduli Kita (Kapeta) adalah sebuah lembaga swadaya masyarakat yang didirikan melalui kepedulian sebuah komunitas yang terdiri dari psikolog, praktisi pendidikan dan para orang tua yang memiliki pengalaman dengan masalah Gangguan Penggunaan Zat di antara keluarga dan lingkungannya. Kapeta memulai kegiatan sejak Juni 2002 melalui pertemuan dukungan untuk orang tua (Family Support Group) dan program terapi Gangguan Penggunaan Zat rawat jalan (Daycare), hingga kemudian resmi didirikan dengan berbadan hukum Yayasan pada tanggal 24 Februari 2004. Melalui berbagai program terkait penanggulangan masalah Gangguan Penggunaan Zat (NAPZA) dan HIV / AIDS Yayasan Kapeta berusaha untuk dapat membantu pemulihan orang-orang dengan masalah Gangguan Penggunaan Zat untuk dapat kembali ke fungsi sosialnya di masyarakat dan memberikan dukungan sosio-psikologis bagi para ODHA (Orang Dengan HIV AIDS) dalam menapaki kehidupannya. Masih terbatasnya penyebaran pendampingan, informasi dan edukasi terkait masalah Gangguan Penggunaan Zat dan HIV / AIDS di Indonesia. Dalam kegiatan operasionalnya tentunya tidak terlepas dari transaksi kas. Dimana yayasan akan menerima berbagai kumpulan dana dari beberapa pihak yang membantu baik dalam bentuk uang, barang maupun jasa. Yayasan juga akan mengeluarkan kas untuk membayar segala beban yang dipergunakan untuk mendukung kegiatan operasionalnya. Dalam kegiatan penerimaan dan pengeluaran ini, bisa terjadi penyelewangan. Sehingga yayasan 
membutuhkan pengendalian internal terhadap siklus penerimaan dan pengeluaran kas untuk mencegah yayasan dari adanya penyalahgunaan kas yayasan demi kepentingan pribadi. Oleh karena itu, peneliti tertarik untuk meneliti sejauh mana dampak internal control pada pengelolaan siklus kas dalam organisasi di Yayasan Kapeta wilayah Tangerang Selatan.

Seiring dengan perkembangan usaha diperlukan prosedur-prosedur dalam upaya pengendalian intern. Pengendalian intern meliputi semua perencanaan dari suatu organisasi dan semua metode serta prosedur yang diterapkan manajemen dengan tujuan antara lain untuk: 1). Menjaga asset perusahaan dari pencurian, pembobolan, perampokan, manipulasi, korupsi yang dilakukan (fraud) oleh pihak-pihak tertentu, serta penggunaan harta kekayaan perusahaan yang tidak diotorisasi. 2). Meningkatkan akurasi dan kepercayaan dari catatan akuntansi dengan cara mengurangi risiko kesalahan dalam proses akuntansi yang dilakukan. Prinsip-prinsip pokok pengendalian intern terdiri dari 1. Pembentukan pertanggungjawaban (establishment of responsibility); 2. Adanya pemisahan tugas secara tegas (segregation of duties); 3. Prosedur dokumentasi harus dimiliki perusahaan (documentation procedure); 4. Pengendalian secara fisik, mekanik, dan elektronik (physical, mechanical and electronic controls); 5. Verifikasi internal yang independen harus ada (independent internal verification).

Setiap kegiatan yayasan akan melibatkan siklus kas, baik itu merupakan transaksi penerimaan maupun pengeluaran kas dan transaksi-transaksi yang lain akan berakhir dengan rekening kas ini. Kas merupakan harta yang paling lancar, paling mudah diselewengkan, maka diperlukan suatu sistem dan prosedur akuntansi untuk mencatat dan mengendalikan kas. Menurut PSAK No. 1 menyatakan bahwa kas adalah alat pembayaran yang siap dan bebas digunakan untuk membiayai kegiatan umum perusahaan. Kas dan setara kas menurut PSAK No. 2 menyatakan kas terdiri dari saldo kas (cash on hand) dan rekening giro. PSAK No. 2, paragraf 6 menjelaskan setara kas dimiliki untuk memenuhi komitmen kas jangka pendek, bukan untuk investasi atau tujuan lain. Penerimaan kas adalah suatu catatan yang dibuat untuk melakukan kegiatan penerimaan kas yang diterima perusahaan, baik yang berupa uang tunai maupun yang berupa surat-surat berharga yang sifatnya dapat segera digunakan seperti cek. Penerimaan kas dapat diperoleh dari berbagai sumber, antara lain penerimaan dari transaksi pelunasan piutang, penjualan tunai, ataupun penerimaan kas yang berasal dari penjualan aktiva tetap perusahaan.

Akuntansi terhadap kas lebih dititik beratkan pada fungsi penyediaan informasi untuk kepentingan manajemen terhadap kas. Secara garis besar akuntansi terhadap kas harus diarahkan kepada dua hal yaitu: Administrative dan Accounting Control, yang secara umum terdiri dari: 1. Menyediakan kas yang cukup untuk operasi perusahaan sehari-hari; 2. Menghindarkan terjadinya kas yang menganggur (idle money) 3. Mencegah terjadinya kerugian-kerugian sebagai akibat dari adanya penyalahgunaan terhadap kas.

Adanya suatu pengendalian intern yang memadai, merupakan syarat mutlak demi perlindungan dan keamanan terhadap kas. Sistem pengendalian intern meliputi semua sarana, alat dan peraturan-peraturan yang digunakan oleh perusahaan dengan tujuan untuk 1. Mengamankan dan mencegah terjadinya pemborosan, penyalahgunaan dan ketidak-efisiensian dari sumber ekonomi yang dimiliki perusahaan; 2. Menjamin ketelitian dan dapat dipercayainya (reliability) keberadaan data operasional dan akuntansi yang dihasilkan; 3. Mendorong tercapainya efisiensi operasi dan dipatuhinya kebijaksanaan manajemen.

$$
\text { Kegiatan Pengabdian Kepada }
$$

Masyarakat dari tim dosen dan mahasiswa Universitas Pamulang hadir di Yayasan Karya Peduli Kita (Kapeta) dalam bentuk peyuluhan dan penjelasan siklus kas, Internal Control dan dampak internal control pada pengelolaan siklus kas. Dalam pelaksanaan pengabdian kepada masyarakat kami memberikan wawasan dan pemahaman kepada pengurus yayasan terkait dampak internal control pada pengelolaan siklus kas dalam organisasi. Selanjutnya, pemberian contoh pengendalian internal siklus kas untuk membentuk kedisiplinan dalam pelaporan penerimaan dan pengeluaran kas. 
Dalam kegiatan operasional yayasan akan menerima berbagai kumpulan dana dari donatur dalam bentuk uang, barang maupun jasa. Yayasan juga akan mengeluarkan kas untuk membayar segala beban keperluan kegiatan operasionalnya. Dalam penerimaan dan pengeluaran kas, bisa terjadi penyelewangan. sehingga yayasan membutuhkan pengendalian internal terhadap siklus penerimaan dan pengeluaran kas sebagai upaya mencegah adanya penyalahgunaan kas demi kepentingan pribadi. Dari penyuluhan yang dilakukan pengurus memperoleh pemahaman tentang pengendalian kas antara lain sebagai berikut:

a. Adanya pemisahan tugas dan tanggungjawab antara yang menerima dan yang mengeluarkan kas dengan yang melakukan pencatatan, memberikan otoritas atas pengeluaran dan penerimaan kas dan bank;

b. Pengurus yang membuat rekonsiliasi bank harus berbeda dengan pegawai yang mengerjakan buku bank dan harus ditreview oleh kepala bagian akuntansi;

c. Digunakannya impress fund system untuk mengelola kas kecil;

d. Penerimaan kas, cek \& giro harus di setor ke bank dalam jumlah seutuhnya;

e. Uang kas disimpan di tempat yang aman dan dikelola dengan baik.

f. Dengan demikian pengelolaan kas di Yayasan akan menjadi lebih baik dan akuntabel daripada sebelum adanya pemahaman tentang internal control dalam pengelolaan kas.

\section{METODE}

Dalam kegiatan ini metode yang diterapkan diharapkan dapat memberikan kemudahan kepada pengurus Yayasan dengan cara memberikan penjelasan wawasan tentang siklus kas, internal control terhdap kas dan dampaknya terhadap organisasi. Selain itu dilakukan diskusi, sharing, tanyajawab, praktik yang dipandu oleh pemateri. Pada metode penjelasan, instruktur menyampaikan materi terkait dengan pengendalian kas dengan membuat tampilan visual berupa slide power point yang ditampilkan ke layar dengan proyektor.

Instruktur dalam menyampaikan penjelasan juga memasukkan unsur "sharing" atau berbagi pengalaman mengenai pengelolaan kas berdasarkan pengelaman dimiliki pemateri, diharapkan dapat memberikan gambaran lebih jelas kepada peserta. Pada metode praktik, peserta membuat disain format perencanaan pengendalian kas dan diajarkan bagaimana tahapan dalam melakukan pengendalian kas. Dengan demikian para peserta yang merupakan pengurus mampu memahami, mengaplikasikan dalam pengelolaan kas Yayasan.

\section{HASIL DAN PEMBAHASAN}

Kegiatan Pengabdian Kepada Masyarakat ini berkaitan erat dengan upaya pengurus yaysan menciptakan pengelolaan dan pengendalian kas secara benar berdasarkan prosedur tertentu, sehingga mampu memberikan tingkat kepercayaan kepada donatur yang memberikan bantuan melaui Yayasan.

Banyaknya bantuan yang diterima dalam betuk tunai, merupakan ujian tersendiri bagi pengurus dalam mengelola dana yang diterima serta banyaknya kegiatan dalam menjalankan program yang telah disusun dalam waktu tertentu. Adanya kendala-kendala yang timbul di lapangan, dalam pelaporan keuangan diataranya terjadinya ketidaksesuaian saldo catatan kas dengan jumlag kas secara nyata, baik yang terdapat di rekening bank atau kas yang dalam bentuk petty cash. Oleh sebab itu, pengurus harus melakukan penghitungan ulang terhadap selisih yang terjadi.

Apabila pegurus telah memiliki wawasan dan pemahaman tentang pengelolaan kas, maka terhadap kesalahan pelaporan dan/atau penyajian saldo kas tidak terjadi. Hal tersebut diperlukan adanya suatu prosedur yang standar dan baku yang ditetapkan oleh pimpinan Yayasan sebagai panduan dalam pengelolaan kas Yayasan. Banyaknya sumbangan yang diterima dari para dontur, merupakan pertimbangan yang sangat penting dalam upaya memberikan informasi yang valid terhadap pengelolaan kas yayasa untuk menjaga tingkat kepercayaan yang telah diberikan selama ini.

Dengan semangat untuk melakukan perbaikan, maka suatu bentuk pengendalian kas harus dibentuk berdasarkan teori-teori dan praktik yang ada. Oleh karena itu, Sistem 
pengendalian intern tidak dirancang untuk dapat mendeteksi adanya kesalahankesalahan, tetapi lebih kepada usaha-usaha pencegahan dan mengurangi kemungkinan terjadinya kesalahan dan penyalahgunaan sehingga harus ada pemisahan fungsi operasi, pencatatan dan penyimpanan dalam segala bidang kegiatan yayasan. Fungsifungsi suatu pengendalian yang dibentuk akan dapat berjalan apabila terdapat tekad dan komitmen untuk menjalankan prosedur tersebut

Berhubungan dengan kas, adanya pemisahan antara pengelola fisik uang (penerimaan, penyimpanan dan pengeluaran) dan pengelolan administrasinya mutlak diperlukan. Dalam fungsi penerimaan kas; pengawasan harus ditujukan agar semua uang yang seharusnya diterima, benar-benar diterima dan dicatat. Fungsi pengeluaran kas; pengawasan harus diarahkan agar tidak terjadi pengeluaran kas tanpa adanya otorisasi oleh pejabat yang berwenang.

Prosedur pengawasan terhadap penerimaan uang sebagai berikut: harus ditunjukkan dengan jelas fungsi-fungsi dalam penerimaan kas harus segera dicatat dan disetor ke bank; melakukan pemisahan fungsi antara pengurusan kas dengan fungsi pencatatan kas harus dibuat laporan kas harian. Sedangkan Prosedur pengawasan terhadap pengeluaran uang sebagai berikut: semua pengeluaran uang menggunakan cek kecuali untuk pengeluaran kecil dibayar melalui kas kecil; penulisan cek hanya dilakukan apabila didukung bukti-bukti yang lengkap atau dengan kata lain digunakan sistem voucher; dipisahkan antara orang yang mengumpulkan bukti pengeluaran, mengisi cek, yang menandatangani cek dan yang mencatat pengeluaran kas; serta lakukan pemeriksaan intern dengan jangka waktu yang tidak tertentu. Dengan adanya pengendalian kas, diharapkan mampu menghasilkan laporan yang andal, dapat menciptakan efisiensi dan efektivitas kegiatan operasi serta patuh terhadap peraturan yang berlaku.

\section{PENUTUP}

Hasil kegiatan PKM di Yayasan Karya Peduli Kita (Kapeta) berjalan dengan lancar. peserta terlihat fokus dan antusias dalam pengikuti kegiatan. Selain itu kegiataan ini memberikan motivasi dan wawasan baru bagi peserta dan pengurus untuk lebih peduli tertib administrasi dan perduli tentang pentingnya suatu pengendalian internal, khususnya dalam pengelolaan kas yang ada di Yayasan tersebut.

\section{DAFTAR PUSTAKA}

Arens. 2008. Audit dan Jasa Assurance: Pendekatan Terpadu (Adaptasi Indonesia), Jakarta: Salemba Empat.

Ikatan Akuntan Indonesia. 2019. Pernyataan Standar Akuntansi Keuangan (PSAK) Jakarta: Salemba Empat.

Manoppo, Rannita Margaretha. 2013. "Analisis Sistem Pengendalian Internal Penerimaan dan Pengeluaran Kas Pada PT. Sinar Galesong Prima Cabang Manado". Dalam Jurnal Fakultas Ekonomi dan Bisnis Jurusan Akuntansi Universitas Sam Ratulangi Manado. Vol 1 no. shttps://ejournal.unsrat.ac.id/index.p hp/emba/article/view/2837/23. Diakses pada tanggal 3 April 2018.

Soemarso. (2008). Akuntansi Suatu Pengantar, Edisi Ke Lima, Buku Ke Satu. Jakarta: Salemba Empat

Pratiwi, F. S. (2017). Pengaruh Pengendalian internal teradap pencegahan frauddan dampaknya pada kinerja perusahaan. 